\title{
PENERAPAN PENDIDIKAN KARAKTER DI KALANGAN MAHASISWA
}

\author{
Rosa Susanti \\ Dosen Tetap STKIP Abdi Pendidikan Payakumbuh \\ e-mail: roza_susantimpd@yahoo.com
}

\begin{abstract}
Education system in Indonesia is often in the spotlight, not only through print and electronic media, but also through cyberspace. Education in Indonesia is often tarnished by rampant incidents that are not well done by the students, ranging from engaging Drugs, promiscuity, fighting, until the murder. The problem occurs not only due to the lack of control of the parents, but also from school. Therefore, today a lot of changes in our education system, one of them are Character Education. The character education teaches habitual ways of thinking and behavior that help learners to live and work together with families, communities, and countries and help them to make decisions that can be accounted for. Because the character is not formed instantaneously, but must be trained seriously, continuous and proportionate in order to achieve the ideal form of character.
\end{abstract}

\begin{abstract}
Abstrak: Sistem pendidikan Indonesia yang kurang baik senantiasa diobral di media elektronik hingga ke dunia maya (internet). Pendidikan di Indonesia cenderung dinodai oleh peristiwa-peristiwa yang mengerikan seperti siswa yang menggunakan obat-obatan terlarang, pemerkosaan, perkelahian pelajar serta pembunuhan. Hal ini terjadi tidak hanya disebabkan karena lemahnya kontrol dari orang tua, tetapi juga dari pihak sekolah. Oleh karena itu, pemerintah merasa perlu untuk merobah sistem pendidikan dengan memasukkan pendidikan karakter. Pendidikan karakter mengajarkan kebiasaan cara berpikir dan berperilaku sehingga mereka mampu hidup dan bekerjasama dengan keluarga, masyarakat, negara, dan membantu mereka dalam membuat keputusan yang tepat. Karena pendidikan karakter tidak bisa dibentuk secara instan maka mahasiswa harus dilatih secara serius, berkelanjutan dan seimbang untuk mencapai karakter yang ideal.
\end{abstract}

Kata Kunci: pendidikan karakter, kontrol orang tua, cara berpikir, bekerjasama, karakter yang ideal

\section{PENDAHULUAN}

Pendidikan merupakan salah satu pilar yang ikut menopang berdirinya sebuah peradaban yang disebut dengan Bangsa. Eksistensi suatu bangsa sangat ditentukan oleh karakter yang dimilikinya. Bangsa yang memiliki karakter kuat dapat menjadi bangsa yang bermartabat dan disegani oleh bangsa lain di seluruh dunia. Menjadi sebuah bangsa yang berkarakter sudah menjadi tujuan bangsa Indonesia. Hal ini sesuai dengan Fungsi Pendidikan Nasional yang tertuang dalam UU No 20 Tahun 2003 tentang Sistem Pendidikan Nasional yaitu Pendidikan nasional berfungsi mengembangkan kemampuan dan membentuk watak serta peradaban bangsa yang bermartabat dalam rangka mencerdaskan kehidupan bangsa, bertujuan untuk berkembangnya potensi peserta didik agar menjadi manusia yang beriman dan bertakwa kepada Tuhan Yang Maha Esa, berakhlak mulia, sehat, berilmu, cakap, kreatif, mandiri, dan menjadi warga negara yang demokratis serta bertanggung jawab.

Berangkat dari hal tersebut diatas, secara formal upaya menyiapkan kondisi, sarana/ prasarana, kegiatan, pendidikan, dan kurikulum yang mengarah kepada pembentukan watak dan budi pekerti generasi muda bangsa memiliki landasan yuridis yang kuat. Namun, sinyal tersebut baru disadari ketika terjadi krisis akhlak yang menerpa semua lapisan masyarakat. Tidak terkecuali juga pada anak-anak usia sekolah. Untuk mencegah lebih parahnya krisis akhlak, kini upaya tersebut mulai dirintis melalui Pendidikan Karakter bangsa.

Pendidikan karakter sebenarnya bukan hal yang baru bagi masyarakat Indonesia. Bahkan sejak awal kemerdekaan, masa orde lama, masa orde baru, dan kini orde reformasi telah banyak langkah-langkah yang sudah dilakukan dalam kerangka pendidikan karakter dengan nama dan bentuk yang berbeda-beda. Dalam UU tentang pendidikan nasional yang pertama kali, ialah UU 1946 yang berlaku tahun 
1947 hingga UU Sisdiknas Nomor 20 tahun 2003 yang terakhir pendidikan karakter telah ada, namun belum menjadi fokus utama pendidikan. Pendidikan akhlak (karakter) masih digabung dalam mata pelajaran agama dan diserahkan sepenuhnya pada guru agama. Karena pelaksanaan pendidikan karakter hanya diserahkan kepada guru agama saja. Maka wajar hingga saat ini pendidikan karakter belum menunjukkan hasil yang optimal. Hal ini terbukti dari fenomena sosial yang menunjukkan perilaku yang tidak berkarakter. Perilaku yang tidak berkarakter itu misalnya sering terjadinya tawuran antar pelajar, adanya pergaulan bebas, dan adanya kesenjangan sosial-ekonomi-politik di masyarakat, kerusakan lingkungan yang terjadi di seluruh pelosok negeri, masih terjadinya ketidakadilan hukum, kekerasan dan kerusuhan, dan korupsi yang mewabah dan merambah pada semua sektor kehidupan masyarakat, tindakan anarkis, konflik sosial. Masyarakat Indonesia yang dahulu terbiasa santun dalam berprilaku, musyawarah mufakat dalam menyelesaikan masalah, mempunyai kearifan lokal yang kaya dengan pluralitas, serta bersikap toleran dan gontongroyong kini mulai cenderung berubah menjadi hegemoni kelompok-kelompok yang saling mengalahkan dan berperilaku tidak jujur.

Pendidikan karakter tidak hanya diterapkan di SD, SMP, dan SMA, tapi juga di tingkat Perguruan Tinggi. Oleh karena itu, tulisan ini akan membahas bagaimana menerapkan pendidikan karakter di kalangan mahasiswa, guna menghasilkan calon pemimpin bangsa yang tidak hanya mampu di bidang akademik, namun juga terpuji secara karakternya.

\section{KONSEP DASAR PENDIDIKAN KARAK- TER}

\section{Pengertian Pendidikan Karakter}

Menurut Kemendiknas (2011,

Pendidikan karakter adalah usaha menanamkan kebiasaan-kebiasaan yang baik (habituation) sehingga peserta didik mampu bersikap dan bertindak bersadarkan nilai-nilai yang telah menjadi kepribadiannya. Dan juga pembangunan karakter dilakukan dengan pendekatan sistematik dan integrative dengan melibatkan keluarga, satuan pendidikan, pemerintah, masyarakat sipil, anggota legsilatif, media massa, dunia usaha, dan dunia industry (Kemendiknas, 2010).

Menurut Murphy $(1998,22)$ pendidikan karakter adalah pendidikan yang didasarkan pada nilai-nilai etika inti berakar dalam masyarakat demokratis, khususnya, penghargaan, tanggung jawab, kepercayaan, keadilan dan kejujuran, kepedulian, dan kemasyarakatan kebajikan dan kewarganegaraan. Dari pengertian di atas nampak bahwa pendidikan karakter mengacu pada proses penanaman nilai, berupa pemahaman-pemahaman, tata cara merawat dan menghidupi nilai-nilai itu, serta bagaimana seorang siswa memiliki kesempatan untuk dapat melatihkan nilai-nilai tersebut secara nyata

Lickona (1991) menambahkan pendidikan karakter adalah segala usaha yang dapat dilakukan untuk mempengaruhi karakter siswa. Lebih jelas Lickona menyatakan bahwa pengertian pendidikan karakter adalah suatu usaha yang disengaja untuk membantu seseorang sehingga ia dapat memahami, memperhatikan, dan melakukan nilai-nilai etika yang sebenarnya.

Hurlock (1993) menjelaskan bahwa perkembangan anak dipengaruhi oleh sekurangkurangnya enam kondisi lingkungannya yaitu: hubungan antar pribadi yang menyenangkan, keadaan emosi, metode pengasuhan anak, peran dini yang diberikan kepada anak, struktur keluarga di masa kanak-kanak dan rangsangan terhadap lingkungan sekitarnya. Enam faktor inilah yang menurut Megawangi (2004) yang menjadi titik pijak pembentukan karakter yang baik. Pendidikan karakter yang dimasudkan disini lebih berkaitan dengan bagaimana menanamkan nilai-nilai tertentu dalam diri anak didik, seperti nilai-nilai yang berguna bagi pengembangan pribadinya sebagai mahluk individual sekaligus sosial dalam lingkungan sekolah.

Dari uraian di atas dapat disimpulkan bahwa pendidikan karakter merupakan pendidikan nilai, pendidikan budi pekerti, pendidikan moral, pendidikan watak, yang bertujuan mengembangkan kemampuan peserta didik untuk memberikan keputusan baik-buruk, 
memelihara apa yang baik, mewujudkan dan menebar kebaikan itu dalam kehidupan seharihari dengan sepenuh hati.

\section{Tujuan dan Fungsi Pendidikan karakter}

Pendidikan memiliki peran fundamental di dalam pengembangan personal dan sosial, untuk mempercepat laju pembangunan manusia yang harmonis sehingga dapat mengentaskan manusia dari kemiskinan, ketertinggalan, kebodohan, kekerasan, dan peperangan, begitu juga dengan pendidikan karakter. Menurut Kemendiknas $(2011,2)$ Pendidikan karakter bertujuan mengembangkan nilai-nilai yang membentuk karakter bangsa yaitu Pancasila, meliputi : (1) mengembangkan potensi peserta didik agar menjadi manusia berhati baik, berpikiran baik, dan berprilaku baik; (2) membangun bangsa yang berkarakter Pancasila; (3) mengembangkan potensi warganegara agar memiliki sikap percaya diri, bangga pada bangsa dan negaranya serta mencintai umat manusia.

Ramli (2003) menambahkan bahwa pendidikan karakter memiliki esensi dan makna yang sama dengan pendidikan moral dan pendidikan akhlak. Tujuannya adalah membentuk pribadi anak, supaya menjadi manusia yang baik, warga masyarakat, dan warga Negara yang baik. Adapun kriteria manusia yang baik, warga masyarakat yang baik, dan warga negara yang baik bagi suatu masyarakat atau bangsa, secara umum adalah nilai-nilai sosial tertentu, yang banyak dipengaruhi oleh budaya masyarakat dan bangsanya. Oleh karena itu, hakikat dari pendidikan karakter dalam konteks pendidikan di Indonesia adalah pendidikan nilai, yakni pendidikan nilai-nilai luhur yang bersumber dari budaya bangsa Indonesia sendiri, dalam rangka membina kepribadian generasi muda.

Pendidikan Karakter juga bertujuan meningkatkan mutu penyelenggaraan dan hasil pendidikan di sekolah yang mengarah pada pencapaian pembentukan karakter dan akhlak mulia peserta didik secara utuh, terpadu, dan seimbang sesuai dengan standar kompetensi kelulusan. Melalui pendidikan karakter, diharapkan peserta didik mampu secara mandiri meningkatkan dan menggunakan pengetahuaan- nya, mengkaji dan menginternalisasi serta mempersonalisasi nilai-nilai karakter dan akhlak mulia sehingga terwujud dalam perilaku seharihari.

Dari penjelasan di atas maka dapat di artikan bahwa Pendidikan karakter pada intinya bertujuan membentuk bangsa yang tangguh, kompetitif, berakhlak mulia, bermoral, bertoleran, bergotong royong, berjiwa patriotik, berkembang dinamis, berorientasi ilmu pengetahuan dan teknologi. Yang semuanya dijiwai oleh iman dan takwa kepada Tuhan yang Maha Esa berdasarkan Pancasila.

Sedangkan fungsi Pendidikan karakter menurut Kemendiknas (2011,2) adalah (1) membangun kehidupan kebangsaan yang multikultural; (2) membangun peradaban bangsa yang cerdas, berbudaya luhur, dan mampu berkontribusi terhadap pengembangan kehidupan ummat manusia; mengembangkan potensi dasar agar berhati baik, berpikiran baik, dan berperilaku baik serta keteladanan baik; (3) membangun sikap warganegara yang cinta damai, kreatif, mandiri, dan mampu hidup berdampingan dengan bangsa lain dalam suatu harmoni.

Sebagai tambahan Badan Penelitian dan Pengembangan, Pusat Kurikulum Kementrian Pendidikan Nasional (2010) menjelaskan secara rinci tentang fungsi pendidikan karakter sebagai berikut:

a. Mengembangkan potensi kalbu/nurani/ afektif peserta didik sebagai manusia dan warga negara yang memiliki nilai-nilai budaya dan karakter bangsa

b. Mengembangkan kebiasaan dan perilaku peserta didik yang terpuji dan sejalan dengan nilai-nilai universal dan tradisi budaya bangsa yang religious

c. Menanamkan jiwa kepemimpinan dan tanggung jawab peserta didik sebagai generasi penerus bangsa

d. Mengembangkan kemampuan peserta didik menjadi manusia yang mandiri, kreatif, berwawasan kebangsaan

e. Mengembangkan lingkungan kehidupan sekolah sebagai lingkungan belajar yang aman, jujur, penuh kreativitas dan persahabatan, serta dengan rasa kebangsaan yang tinggi dan penuh kekuatan. 
Pusat Kurikulum Kemendiknas (2010) menyatakan bahwa secara khusus pendidikan karakter memiliki tiga fungsi utama, yaitu:

\section{a. Pembentukan dan Pengembangan Potensi}

Pendidikan karakter berfungsi membentuk dan mengembangkan potensi manusia atau warga negara Indonesia agar berpikiran baik, berhati baik, dan berperilaku baik sesuai dengan falsafah hidup Pancasila.

b. Perbaikan dan Penguatan

Pendidikan karakter berfungsi memperbaiki karakter manusia dan warga negara Indonesia yang bersifat negatif dan memperkuat peran keluarga, satuan pendidikan, masyarakat, dan pemerintah untuk ikut berpartisipasi dan bertanggung jawab dalam pengembangan potensi manusia atau warga negara menuju bangsa yang berkarakter, maju, mandiri, dan sejahtera.

\section{c. Penyaring}

Pendidikan karakter bangsa berfungsi memilah nilai-nilai budaya bangsa sendiri dan menyaring nilai-nilai budaya bangsa lain yang positif untuk menjadi karakter manusia dan warga negara Indonesia agar menjadi bangsa yang bermartabat.

Dapat disimpulkan bahwa fungsi pendidikan karakter adalah mengembangkan potensi dasar agar berhati baik, berpikiran baik, dan berperilaku baik, kemudian memperkuat dan membangun perilaku bangsa yang multikultur dan meningkatkan peradaban bangsa yang kompetitif dalam pergaulan dunia.

\section{Nilai-nilai Pembentuk Pendidikan Karakter}

Pusat Kurikulum Depdiknas (2010) menyatakan bahwa dalam rangka lebih memperkuat pelaksanaan pendidikan karakter pada satuan pendidikan telah teridentifikasi 18 nilai yang bersumber dari agama, Pancasila, budaya, dan tujuan pendidikan nasional, yaitu:

(1). Religius:

Sikap dan prilaku yang patuh dalam melaksanakan ajaran agama yang dianutnya, toleran terhadap pelaksanaan ibadah agama lain, dan hidup rukun dengan pemeluk agama lain

(2) Jujur :

Prilaku yang didasarkan pada upaya menjadikan dirinya sebagai orang yang selalu dapat dipercaya dalam perkataan, tindakan, dan pekerjaan.

(3) Toleransi:

Sikap dan tindakan yang menghargai perbedaan agama, suku, etnis, pendapat, sikap, dan tindakan orang lain yang berbeda dari dirinya

(4) Disiplin:

Tindakan yang menunjukkan perilaku tertib dan patuh pada berbagai ketentuan dan peraturan

(5) Kerja keras:

Tindakan yang menunjukkan perilaku tertib dan patuh pada berbagai ketentuan dan peraturan.

(6) Kreatif:

Berpikir dan melakukan sesuatu untuk menghasilkan cara atau hasil baru dari sesuatu yang telah dimiliki

(7) Mandiri:

Sikap dan prilaku yang tidak mudah tergantung pada orang lain dalam menyelesaikan tugas-tugas

(8) Demokratis:

Cara berfikir, bersikap, dan bertindak yang menilai sama hak dan kewajiban dirinya dan orang lain

(9) Rasa Ingin Tahu:

Sikap dan tindakan yang selaku berupaya untuk mengetahui lebih mendalam dan meluas dari sesuatu yang dipelajarinya, dilihat, dan didengar.

(10) Semangat Kebangsaan:

Cara berpikir, bertindak, dan berwawasan yang menempatkan kepentingan bangsa dan Negara di atas kepentingan diri dan kelompoknya

(11) Cinta Tanah Air:

Cara berpikir, bertindak, dan berwawasan yang menempatkan kepentingan bangsa dan Negara di atas kepentingan diri dan kelompoknya 
(12) Menghargai Prestasi:

Sikap dan tindakan yang mendorong dirinya untuk menghasilkan sesuatu yang berguna bagi masyarakat, dan mengakui, serta menghormati keberhasilan orang lain.

(13)Bersahabat/Komunikatif:

Sikap dan tindakan yang mendorong dirinya untuk menghasilkan sesuatu yang berguna bagi masyarakat, dan mengakui, serta menghormati keberhasilan orang lain.

(14) Cinta Damai:

Sikap dan tindakan yang mendorong dirinya untuk menghasilkan sesuatu yang berguna bagi masyarakat, dan mengakui, serta menghormati keberhasilan orang lain.

(15) Gemar Membaca:

Kebiasaan menyediakan waktu untuk membaca berbagai bacaan yang memberikan kebajikan bagi dirinya

(16) Peduli Lingkungan:

Sikap dan tindakan yang selalu berupaya mencegah kerusakan pada lingkungan alam disekitarnya, dan mengembangkan upayaupaya untuk memperbaiki kerusakan alam yang sudah terjadi

(17) Peduli Sosial:

Sikap dan tindakan yang selalu ingin member bantuan pada orang lain dan masyarakat yang membutuhkan.

(18) Tanggung Jawab:

Sikap dan perilaku seseorang untuk melaksanakan tugas dan kewajibannya, yang seharusnya dia lakukan, terhadap diri sendiri, masyarakat, lingkungan (alam, sosial, dan budaya), Negara dan Tuhan Yang Maha Esa.

Selanjutnya Lickona (1991) menjelaskan Pendidikan karakter diperlukan guna membuat peserta didik menyadari pentingnya memahami nilai-nilai yang ada di masayarat dengan beberapa alasan, di antaranya: (1) Banyaknya generasi muda saling melukai karena lemahnya kesadaran pada nilai-nilai moral, (2) Memberikan nilai-nilai moral pada generasi muda merupakan salah satu fungsi peradaban yang paling utama, (3) Peran sekolah sebagai pendidik karakter menjadi semakin penting ketika banyak anak-anak memperoleh sedikit pengajaran moral dari orangtua, masyarakat, atau lembaga keagamaan, (4) masih adanya nilai-nilai moral yang secara universal masih diterima seperti perhatian, kepercayaan, rasa hormat, dan tanggungjawab, (5) Demokrasi memiliki kebutuhan khusus untuk pendidikan moral karena demokrasi merupakan peraturan dari, untuk dan oleh masyarakat, (6) Tidak ada sesuatu sebagai pendidikan bebas nilai. Sekolah mengajarkan pendidikan bebas nilai. Sekolah mengajarkan nilai-nilai setiap hari melalui desain ataupun tanpa desain, (7) Komitmen pada pendidikan karakter penting manakala kita mau dan terus menjadi guru yang baik, dan (8) Pendidikan karakter yang efektif membuat sekolah lebih beradab, peduli pada masyarakat, dan mengacu pada performansi akademik yang meningkat.

\section{Kemudian Soetanto}

menambahkan bahwa nilai-nilai luhur yang terkandung di dalam penerapan pendidikan karakter adalah prilaku berkarakter yang secara koheren memancar dari:

a. Olah pikir, meliputi cerdas, kritis, kreatif, inovatif, ingin tahu, berfikir terbuka, produktif, berorientasi Ipteks dan reflektif.

b. Olah hati, meliputi sikap jujur, beriman dan bertakwa, amanah, adil, bertanggung jawab, berempati, berani mengambil resiko, pantang menyerah, rela berkorban, dan berjiwa patriotic.

c. Olah raga, meliputi sikap tangguh, bersih dan sehat, disiplin, sportif, andal, berdaya tahan, bersahabat, kooperatif, determinatif, kompetiyamantif, ceria dan gigih.

d. Olah rasa dan karsa, meliputi sikap peduli, ramah, santun, rapi, nyaman, saling menghargai, toleran, suka menolong, gotong royong, nasionalis, kosmopolit, mengutamakan kepentingan umum, bangga menggunakan bahasa dan produk Indonesia, dinamis, kerja keras, dan beretos kerja.

Jadi secara garis besar dapat disimpulkan bahwa nilai-nilai yang terkandung dalam penerapan pendidikan karakter meliputi nilai-nilai luhur bangsa dan agama. Dalam pelaksanaannya pendidikan karakter dapay dimulai dari nilai yang esensial, sederhana, dan mudah dilaksanakan sesuai dengan kondisi dimana penerapan pendidikan karakter tersebut, contohnya nilai kebersihan, kerapihan, 
kenyamanan, kedisiplinan, kesopanan, dan kesantunan peserta didik.

\section{PENERAPAN PENDIDIKAN KARAKTER DI KALANGAN MAHASISWA}

Menurut kamus bahasa Indonesia, mahasiswa adalah orang yang belajar (peserta didik) di perguruan tinggi (Pusat Bahasa Depdiknas, 2008: 895). Sementara itu Flexner dalam Syukri (2009) berpendapat bahwa perguruan tinggi merupakan tempat pencarian ilmu pengetahuan, pemecahan berbagai masalah, tempat mengkritisi karya-karya yang dihasilkan, dan sebagai pusat pelatihan manusia. Jadi, mahasiswa dididik dan dilatih di perguruan tinggi agar menjadi manusia intelektual yang mempunyai daya nalar tinggi, analisa yang luas dan tajam, berilmu tinggi dan berprilaku terpuji.

Namun, penerapan pendidikan karakter dikalangan mahasiswa banyak menemui kendala, hal ini terlihat pada misi perguruan tinggi yang dijabarkan oleh Arthur dalam Syukri (2009) yaitu pengajaran, penelitian dan aplikasi ilmu pengetahuan, yang secara tersirat membentuk opini bahwa pembentukan karakter bukan tugas perguruan tinggi. Kemudian Schwartz (2000) menyatakan ada beberapa hal yang mengundang kekeliruan terkait penerapan pendidikan karakter dikalangan mahasiswa, yaitu:

1. Karakter seseorang sudah terbemtuk sebelum masuk ke perguruan tinggi dan merupakan tanggung jawab orang tua untuk membentuk karakter anaknya.

2. Perguruan tinggi, khususnya dosen, tidak memiliki kepentingan dengan pembentikan karakter, karena mereka direkrut bukan untuk melakukan hal tersebut.

3. Karakter merupakan istilah yang mengacu pada agama tau ideology konservatif tertentu, sementara itu perguruan tinggi di barat secara umum melepaskan diri dari agama atau idiologi tertentu.

Dari penjelasan diatas dapat disimpulkan bahwa sebenarnya pendidikan karakter di perguruan tinggi dapat melengkap karakter yang sudah terbentuk pada diri mahasiswa yang didapat pada tingkat pendidikan sebelumnya, namun hal tersebut belum berjalan sebagaimana mestinya.

Walaupun demikian, perguruan tinggi di Indonesia harus mengambil tempat dalam menerapkan pendidikan karakter pada diri mahasiswa. Soetanto (2012) menjabarkan bahwa penerapan pendidikan karakter di perguruan tinggi didasarkan pada lima pilar utama:

1. Tri Darma Perguruan Tinggi

Pendidikan karakter bisa diintegrasikan ke dalam kegiatan pendidikan, penelitian dan pengabdian kepada masyarakat yang berkarakter.

2. Budaya Perguruan Tinggi (kampus)/ Budaya Organisasi

Mahasiswa dituntut untuk dapat membiasakan diri dalam kehidupan keseharian di lingkungan perguruan tinggi.

3. Kegiatan Kemahasiswaan

Pendidikan karakter dapat diciptakan melalui integrasi ke dalam kegiatan kemahasiswaan, antara lain pramuka, olahraga, karya tulis, seni, workshop, dan acara yang melibatkan mahasiswa dalam system kepanitiaannya.

4. Kegiatan Keseharian

Pendidikan karakter dapat dimunculkan dengan penerapan pembiasaan kehidupan keseharian di lingkungan keluarga, asrama, dan masyarakat.

5. Budaya Akademik

Nilai pendidikan karakter secara persfektif terbentuk dengan adanya totalitas budaya akademik.

Uraian di atas memberikan gambaran, bahwa pendidikan karakter sebenarnya bisa dengan mudah diterapkan pada mahasiswa, karena setiap unit yang ada diperguruan tinggi mampu menampung pemberdayaan pendidikan karakter. Oleh karena itu semua pihak yang terlibat, tidak hanya dosen sebagai pengampu mata kuliah, namun juga semua civitas akademika, orang tua, masyarakat, dan mahasiswa yang bersangkutan harus bisa bekerja sama dalam rangka penerapan pendidikan karakter.

Adapun penerapannya harus mempunyai strategi guna mencapai hasil yang diinginkan, Soetanto (2012) mengungkapkan bahwa ada 
beberapa strategi yang bisa digunakan dalam penerapan pendidikan karakter:

1. Melalui pembelajaran

Strategi penerapan pendidikan karakter melalui pembelajaran bisa dilakukan melalui 2 cara, yaitu (a) dengan penguatan matakuliah Pendidikan Agama, Pendidikan Pancasila, Pendidikan Kewarganegaraan, Ilmu Alamiah Dasar, dan Ilmu Sosial Budaya Dasar, (b) dengan pengintegrasian pendidikan karakter kesetiap mata kuliah bidang keilmuan, teknologi, dan seni.

2. Melalui ekstrakulikuler

Strategi ini dengan cara menerapkan proses pendidikan karakter melalui kegiatan yang melibatkan mahasiswa di dalamnya, yaitu (a) lembaga kemahasiswaan, seperti Badan Eksekutif Mahasiswa, Keluarga Mahasiswa, Himpunan Mahasiswa, dan Kelompok Belajar, (b) melalui unit kegiatan mahasiswa, seperti pramuka, Menwa, olahraga, pecinta alam, dll.

3. Melalui pengembangan budaya perguruan tinggi

Budaya perguruan tinggi dibagi menjadi tiga unit, (a) budaya akademik, penerapan pendidikan karakter bisa melalui pengembangan ilmu pengetahuan dan teknologi, (b) budaya humanis, disini hubungan harmonis sesame warga perguruan tinggi serta warga perguruan tinggi dengan masyarakat berdasarkan cinta kasih, kepedulian, dan gotong royong diharap mampu mengembangkan pendidikan karakter, (c) budaya religious, pendidikan karakter dapat diterapkan melalui iman dan taqwa kepada Tuhan YME, menjalankan syariat agama, saling menghormati antar sesame pemeluk agama dan antara pemeluk agama lainnya.

Uraian strategi di atas diharapkan mampu melahirkan insan akademis Indonesia yang berkarakter, jujur, cerdas, peduli, dan tangguh. Selain itu perguruan tinggi juga memiliki pilihan dalam mengajarkan pembentukan karakter karena dapat mengintegrasikan dan mengajarkan secara alami dengan mata kuliah pada semua kelas oleh semua pendidik. Walaupun begitu, hal ini tentu saja menimbulkan konsekuensi cara pengajaran yang berbeda dan cara pemberian nilai yang berbeda, dosen tidak hanya mengevaluasi penguasaan teori atau kemampuan kognitif mahasiswa, namun juga mengevaluasi implementasi karakter atau nilai-nilai luhur. Selain itu dosen semua mata kuliah hendaknya menjadi figur yang mempraktekkan pembentukkan karakter ini dalam semua aktivitas di kelas maupun di luar kelas. Apabila hal ini bisa dilakukan, maka dapat mempermudah pembentukan karakter pada setiap individu mahasiswa, sehingga mereka nantinya bisa menjadi pribadi dewasa yang matang dan bertanggung jawab.

\section{SIMPULAN}

Pendidikan karakter di perguruan tinggi sangat diperlukan guna membentuk dan membangun mahasiswa agar menjadi pribadi yang berkarakter sesuai dengan nilai luhur ideologi Negara Indonesia, dan memperkokoh karakter yang didapat mahasiswa pada tingkat pendidikan sebelumnya. Selain itu, pendidikan karakter sangat penting untuk diterapkan di perguruan tinggi karena sudah banyak sarjana yang pintar namun tidak memiliki karakter, sehingga kurang bisa bersaing dengan sarjana dari Negara lain.

Implementasi pendidikan karakter dikalangan mahasiswa tidak hanya harus dilakukan oleh citivas akademika saja, namun juga bekerja sama dengan stakeholder, dalam hal ini orangtua dan masyarakat. Salah satu caranya adalah dengan memberikan atau mengadakan workshop, newsletter, atau pamflet mengenai pemmbentukan karakter mahasiswa dalam keluarga dan masyarakat. Terakhir, perlunya pendalaman konsep secara filosofis ataupun teoritis mengenai pentingnya pendidikan karakter, serta langkah-langkah yang efektif demi berlanjutnya ppendidikan karakter di masa depan. 


\section{DAFTAR RUJUKAN}

Hurlock, B. Elizabeth. 1993. Psikologi Perkembangan. Jakarta: Erlangga

Kemendiknas. 2011. Panduan Pendidikan Karakter. Jakarta: Pusat Kurikulum dan Kebukuan Kemendiknas

Lickona, Thomas, 1991. Educating for character: How our schools can teach respect and responsibility. New York: Bantam Books.

Murphy, M.M. 1998. Character Education in America's Blue Ribbon Schools. Lancaster PA, Technomic

Pusat Bahasa Depdiknas. 2008. Kamus Bahasa Indonesia. Jakarta: Departemen Pendidikan Nasional
Pusat Kurikulum Depdiknas. 2010. Bahan Pelatihan Penguatan Metodologi Pembelajaran Berdasarkan Nilai-nilai Budaya untuk Membentuk Daya Saing dan Karakter Bangsa. Jakarta: Kemendiknas

Schwartz, AJ, 2000. It's Not to Late to Teach College Student about Values. The Chronicle of Higher Education. Vol 46. No 40.pg A68

Soetanto, Hendrawan. 2012. Pendidikan Karakter. Malang: Univ. Brawijaya

Syukri, 2009. Peran Pendidikan di Perguruan Tinggi terhadap Perubahan Perilaku Kaum Intelektual (sosial-Individu). Jurnal Ilmiah Kreatif. vol 6 no 1, hal 1-15. 